\title{
Distribution of saline and freshwater in groundwater in Thai Binh province and solution for reasonable exploitation
}

\author{
Hiện trạng phân bố mặn - nhạt nước dưới đất tỉnh Thái Bình và đề xuất giải \\ pháp khai thác hơp lý \\ Research article
}

Tran, Thi Thanh Thuy ${ }^{*}$; Nguyen, Van Lam ${ }^{1}$; Dang, Huu On ${ }^{2}$

${ }^{1}$ Hanoi University of Mining and Geology, North Tu Liem District, Ha Noi, Vietnam; ${ }^{2}$ Vietnam Association of Geology, Hoan Kiem district, Hanoi, Vietnam

\begin{abstract}
Thai Binh is a coastal province of Red River Delta in Vietnam, having administrative boundaries at the river systems and coastlines that cause groundwater quality varies complicatedly. Today in Thai Binh province, the groundwater in Holocene and Pleistocene aquifers is exploited for domestic use. But, beside the quality of groundwater in this region is not uniform, it is interspersed between salt water and fresh water zones in Holocene and Pleistocene aquifers. Nowaday, under the force of groundwater exploitation activity for domestic purposes, agricultural activities, the impact of climate change and sea level rise issues, the quality of distribution of groundwater here change. According to the recent research results, groundwater quality and distribution of salt water - fresh water there have many changes compared with the research results of the Northern Division for Water resources Planning and Investigation in the year 1996. For the the Holocene aquifer (qh), distribution area of salt water zone has been narrowed. Besides, saline cleaning process occurred in some coastal areas in Tien Hai, Thai Thuy and a part of Quynh Phu district. For the Pleistocene aquifer (qp), compared with research result in 1996, the boundaries between saline and fresh water at the present time is not change so much. By assessing the status of the distribution of saline and fresh water zones in groundwater in Thai Binh and the movement of this boundary, author's research results will be the basis that helps the managers give out reasonable exploiting and sustainable using methods for these natural resources.
\end{abstract}

Thái Bình là một tỉnh ven biển thuộc vùng châu thổ sông Hồng của Việt Nam, được bao bọc bởi hệ thống sông biển khép kín làm cho chất lượng nước ngầm biến đổi rất phức tạp. Hiện nay, tại Thái Bình có 2 tầng chứa nước chính phục vu ăn uống sinh hoạt là tầng chứa nước Holocen và tầng chứa nước Pleistocen. Tuy nhiên, chất lương nước ngầm ở các tầng chứa nước này không đồng đều, có sự phân bố xen kẽ giũa các khoảnh nước mặn và nước nhạt. Hiện nay, duới tác động của hoạt động dân sinh, sản xuất nông nghiệp, khai thác nước phục vu sinh hoạt cùng ảnh hưởng của biến đổi khí hậu và sự dâng cao của mực nước biển đã làm thay đổi chất lượng và quy mô phân bố nước ngầm khu vưc. Theo nhũng kết quả nghiên cưu mới nhất của tác giả cho thấy diện tích phân bố của các vùng nước mặn - nước nhạt của các tầng chứa nước trên địa bàn tỉnh đã có nhiều thay đổi so với kết quả nghiên cúu trước đây của Liên đoàn Địa chất thủy văn-Địa chất công trình miền Bắc năm 1996. Với tầng chứa nước Holocen, diện tích phân bố các khoảnh nước mặn bị co hẹp và đang có sụ nhạt hóa tại một số khu vưc ven biển thuộc Huyện Tiền Hải, Thái Thuyy và một phần thuộc huyện Quỳnh Phu. Trong tầng chứa nước Pleistocen (qp), so với kết quả nghiên cứu năm 1996, ranh giới mặn - nhạt tại thời điểm hiện tại đã có sụ thay đổi nhung không lớn. Kết quả nghiên cứu này là co sở giúp các nhà quản lý đề xuất giải pháp, phân vùng khai thác và sư dụng hợp lý nguồn tài nguyên thiên nhiên này đặc biệt trước tình trạng khan hiếm nước nhu hiện nay trên địa bàn tỉnh Thái Bình.

Keywords: $\quad$ aquifer, groundwater, Holocen, instrution, Pleistocence, rainfall 


\section{Introduction}

Thai Binh is one of coastal provinces in the Red River delta having administrative boundaries at the river systems and coastlines. Research results of previous scientists showed that hydrogeology characteristics of this area are very complex.

The studying area have two main aquifers that are Holocen $\left(\mathrm{qh}_{1}-\mathrm{qh}_{2}\right)$ and Pleistocen (qp) aquifers. These aquifers were separated by clay layer of Hai Hung and Vinh Phuc formation. The distribution of aquifers and aquitards is shown in Figure 1.

\subsection{Upper Holocene unconfined aquifer $\left(q h_{2}\right)$}

This is the uppermost aquifer, which is distributed throughout the studying area. It is mainly composed of fine sand and occasionally with silty sand. The thickness increases from the North - North West to the South - South East, with maximum is $25 \mathrm{~m}$. Groundwater level is from 1 to 2 $\mathrm{m}$ depending on the seasons. Transmissibility coefficient is $1.8 \mathrm{~m}^{2} /$ day, hydraulic conductivity is $1.49 \mathrm{~m}$ /day and storage coefficient is 0.18 .

The chemical composition of $\mathrm{qh}_{2}$ aquifer in saline areas has $\mathrm{Na}-\mathrm{Ka}-\mathrm{Cl}$ type and is shown in the following formula:

$$
M_{11.15} \frac{C l_{92}}{(\mathrm{Na}+\mathrm{K})_{88} M g_{10}} p H_{8.1}
$$



Figure 1. Hydrogeology crossection in Thai Binh province

\subsection{Confined interstitial Pleistocene aquifer (qp)}

This aquifer is distributed throughout the study area and only opened on surface at Quynh Phu district. Its component is mainly composed of fine to medium coarse sand, some gravel and clay. The thickness is from 36 to $61 \mathrm{~m}$ depending on place, average thickness is $57 \mathrm{~m}$. Transmissibility coefficient is $1.8 \mathrm{~m}^{2} /$ day and storage coefficient is 0.18 . We can divide this aquifer into two areas based on total dissovle solids (TDS) value, one part in the North with TDS value lower than $1.0 \mathrm{~g} / 1$ and another in the South with TDS value higher than $1.0 \mathrm{~g} / 1$.
The chemical composition of $\mathrm{qh}_{2}$ aquifer in fresh areas has $\mathrm{Mg}-\mathrm{Na}-\mathrm{Ka}-\mathrm{Cl}$ type and is shown in the following formula:

$$
M_{0.5} \frac{\mathrm{Cl}_{60} \mathrm{HCO}_{37}^{3}}{\mathrm{Mg}_{39}(\mathrm{Na}+\mathrm{K})_{35} \mathrm{Ca}_{26}} \mathrm{pH}_{8.5}
$$

\subsection{Weakly confined lower Holocene aquifer $(\mathbf{q h})$}

This aquifer underlies the upper aquifer $\mathrm{qh}_{2}$ and also is distributed throughout studying area. It is mainly composed of grey quartz mixed with plant humus, and mica. The average thickness is $14.2 \mathrm{~m}$, and hydraulic conductivity is from 0.61 to $1.0 \mathrm{~m} /$ day.

The chemical composition of $\mathrm{qh}_{1}$ aquifer in fresh areas has $\mathrm{Na}-\mathrm{Ka}-\mathrm{Mg}-\mathrm{Cl}$ type and is shown in the following formula:

$$
M_{27.42} \frac{C l_{96}}{(N a+K)_{83} M g_{15}} p H_{8.4}
$$

The previous research results indicated that the groundwater quality of Holocen aquifer is uneven and complicated variability. The main recharge sources for this aquifer were from rainy water and surface water. Water table depends on the meteorological condition. The result of pumping test in some boreholes is from $40 \div 60 \mathrm{~m}^{3} /$ day. The groundwater quality is usually contaminated by microorganisms. Although it is distribiuted at shallow depth, therefore easy to exploit, it cannot be used productively. 
pumping test was about $11.3 \mathrm{l} / \mathrm{day}$, transmissibility coefficient was $1.5 \mathrm{~m}^{2} /$ day and hydraulic conductivity was 22 $\mathrm{m} /$ day.

The aquifer area with TDS higher than $1 \mathrm{~g} / 1$ is distributed in the southern part of the province which under the administrative scope of the Kien Xuong, Tien Hai, Vu Thu districts and a part of Thai Thuy district. TDS value in some places was up to $29 \mathrm{~g} / \mathrm{l}$.

The chemical composition is $\mathrm{Na}-\mathrm{Ka}-\mathrm{Mg}-\mathrm{Ca}-\mathrm{Cl}$ type and is shown in the following formula:

$$
M_{29} \frac{C l_{92}}{(N a+K)_{70} M g_{18} C a_{11}} p H_{8.4}
$$

At the present, the quality and storage of groundwater in Thai Binh province change so much under the impacts of industrialization processes, groundwater exploitation activity for economic purposes,climate change, and sea level rise. To manage and protect this resources, we need to have an overview and the updateed data of the distribution, the quality and storage of groundwater. The authors have done several tasks to solve this question.

\section{Subjects and methodology}

\subsection{Subject}

The study focused mainly on Holocen and Pleistocen aquifers, re-definition of the distribution areas of salt water and fresh water, and detemination of hydrogeology parameters of aquifers.

\subsection{Methodology}

To research and determine the distribution of saline and fresh water areas in Holocene and Pleistocene aquifers in Thai Binh province, the combinatorial hydrogeology methods including outdoor and indoor were used as follow:

- Survey task;

- Geophysical method;

- Pumping test;

- Water sample analysis in laboratory;

- Rapid measurement method;

- Hydrogeology test;

- Establishment of the map.

Purposes of these tasks are to detemine hydraulic relationship between aquifers and surface water, flow direction, physical and chemical characteristics of groundwater, and hydrogeology and geology charateristics of the aquifers.

In this research, more than 90 observation points over the studying area were arranged. Our observed results were combined with other observation results of National Center for Water Resources Planning and Investigation.

To determine the origin formation and the movement of groundwater, especialy the change of the distribution of saline water zones, the following parameters were measured: TDS, $\mathrm{Ca}^{2+}, \mathrm{Mg}^{2+}, \mathrm{K}^{+}, \mathrm{Na}^{+}, \mathrm{HCO}_{3}^{-}$and $\mathrm{Cl}^{-}$. The new boundary distribution of saline and fresh groundwater areas in Thai Binh province was built and compared with the previous research in 1996.

Table 1: Chemical component of groundwater in Thai Binh province

\begin{tabular}{|c|c|c|c|c|c|c|c|c|c|c|c|c|}
\hline \multirow[b]{2}{*}{ No } & \multirow[b]{2}{*}{ Sample } & \multirow[b]{2}{*}{ istrict, aquifer } & \multirow[b]{2}{*}{ pH } & \multirow{2}{*}{$\begin{array}{c}\text { TDS } \\
(\mathrm{mg} / \mathrm{l})\end{array}$} & \multicolumn{5}{|c|}{ Anion, $\mathrm{mg} / \mathrm{l}$} & \multicolumn{3}{|c|}{ Cation, $\mathrm{mg} / \mathrm{l}$} \\
\hline & & & & & $\mathrm{Ca}^{2+}$ & $\mathrm{Mg}^{2+}$ & $\mathrm{K}^{+}$ & $\mathrm{Na}^{+}$ & $\mathrm{Fe}^{3+}$ & $\mathrm{HCO}_{3}^{-}$ & $\mathrm{Cl}^{-}$ & $\mathrm{SO}_{4}{ }^{2-}$ \\
\hline 1 & NN1 & $\mathrm{Vu}$ & 7.4 & & $\begin{array}{c}58.1 \\
2\end{array}$ & 4011 & & 0 & 3.5 & 439.3 & 113.4 & 36.1 \\
\hline 2 & M5 & Vu T & 7.1 & 1,250 & $\begin{array}{c}90.1 \\
6\end{array}$ & 133. & 9 & 15.0 & 3.7 & 99.0 & 1,826 & 2.01 \\
\hline 3 & M4 & Tien & 4.2 & 350 & $\begin{array}{c}40.0 \\
0\end{array}$ & 53.00 & 10.7 & 260.0 & 4.10 & 152.0 & 85.00 & 3.90 \\
\hline 4 & NN13 & $\mathrm{T}$ & 8.5 & 5,820 & $\begin{array}{c}87.2 \\
1\end{array}$ & 138.2 & 42 & 15 & 92 & 09.2 & 4,077 & 2.82 \\
\hline 5 & NN18 & Thai Thuy, qh & 7.9 & 2,860 & $\begin{array}{c}79.1 \\
6\end{array}$ & 106.4 & 36.00 & 895.0 & 4.89 & 598.0 & 1,569 & 2.40 \\
\hline 6 & M6 & Thai Thuy, & 1.2 & 12 & 45.0 & 20.1 & 9.15 & 435.0 & 0.06 & 204.0 & 403.0 & 42.0 \\
\hline 7 & M10 & Dong Hung, qh & 6.70 & 5 & $\begin{array}{c}29.0 \\
0\end{array}$ & 75.00 & 4.00 & 91.63 & 1.40 & 179.0 & 128.0 & 9.70 \\
\hline 8 & $\mathrm{NN} 28$ & Dong Hun & 7.5 & 1,729 & $\begin{array}{c}58.1 \\
2\end{array}$ & 102.1 & 35.5 & 508.0 & 5.93 & 927.5 & 567.2 & 164.5 \\
\hline 9 & NN32 & Hun & 6.9 & 854.0 & $\begin{array}{c}61.1 \\
2\end{array}$ & 54.7 & 5.75 & 165.0 & 19.9 & 170.9 & 460.9 & 2.40 \\
\hline 10 & M7 & Hung Ha, qp & 7.0 & 742 & 23.0 & 96.0 & 3.9 & 76.1 & 2.9 & 328.0 & 162 & 6.00 \\
\hline 11 & M2 & Quynh Phu, $\mathrm{qh}_{2}$ & 6.7 & 545 & 29.0 & 75.0 & 4.0 & 91.63 & 1.40 & 179.0 & 128.0 & 9.70 \\
\hline 12 & M1 & Quynh Phu, qp & 6.76 & 400 & 23.0 & 12.0 & 3.76 & 63.0 & 6.40 & 272.0 & 11 & 5.20 \\
\hline 13 & $\mathrm{NN} 2$ & Kien Xuong, $\mathrm{qh}_{2}$ & 7.4 & 980 & 32.5 & 32.0 & 16.94 & 58.56 & 1.20 & 586.0 & 1,072 & 11.3 \\
\hline
\end{tabular}




$\begin{array}{ccccccccccccc}14 & \text { NN3 } & \text { Kien Xuong, qp } & 7.3 & 1,250 & 80.1 & 156.6 & 66.0 & 1.430 & 3.90 & 1,062 & 2,198 & 18.01 \\ 15 & \text { NN4 } & \text { TP Thai Binh, qh } & 8.0 & 843.0 & \begin{array}{c}56.1 \\ 1\end{array} & 57.15 & 98.5 & 192.5 & 5.75 & 524.77 & 239.3 & 2.4 \\ 16 & \text { NN5 } & \text { TP Thai Binh, qp } & 7.75 & 282.0 & \begin{array}{c}27.5 \\ 0\end{array} & 24.27 & 0.73 & 34.20 & 5.12 & 158.7 & 113.4 & 2.4\end{array}$

\section{Results and discussion}

The collected data of hydrogeology characteristics, the exploitation status of groundwater in 2013 and 2014 are shown in Table 1. The distribution of saline and freshwater areas in Holocene and Pleistocene aquifers was newly drawn (Figure 3).

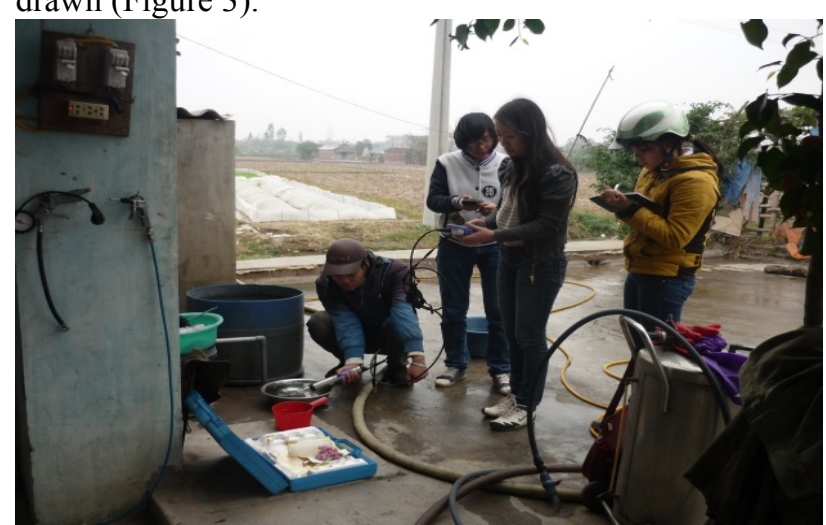

Figure 2. Monitoring the quality of groundwater in Thai Binh province

\subsection{Holocen aquifer $\left(q h_{2}\right)$}

We can see that the shape and the distribution of saline and freshwater areas had many changes.

The areas of freshwater zones with TDS lower than $1 \mathrm{~g} / 1$ have been expanding at the region of Dong Hung and Quynh Phu districts. The areas of saline water zones were narrowed and combined together at the regions of $\mathrm{Vu} \mathrm{Thu}$, Kien Xuong and Tien Hai districts.

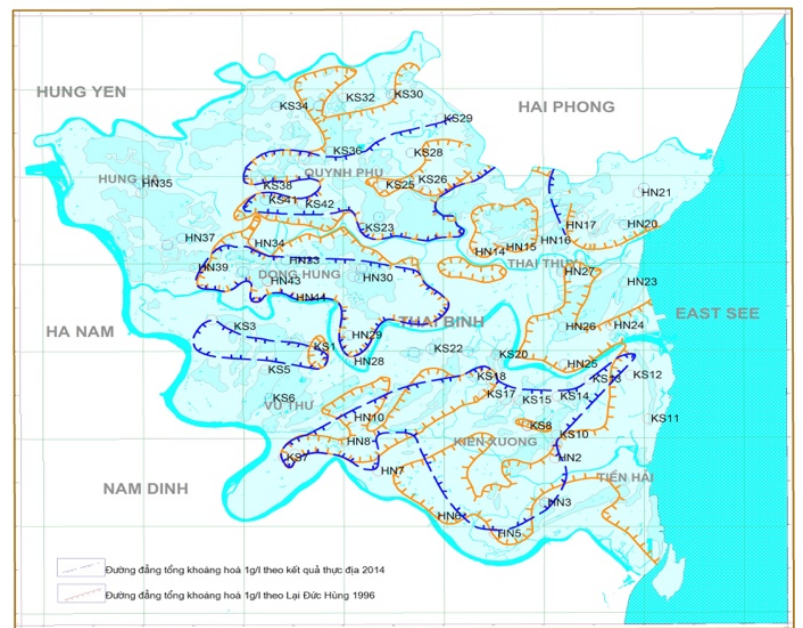

Figure 3. Distribution map of saline and fresh water areas in Holocen aquifer

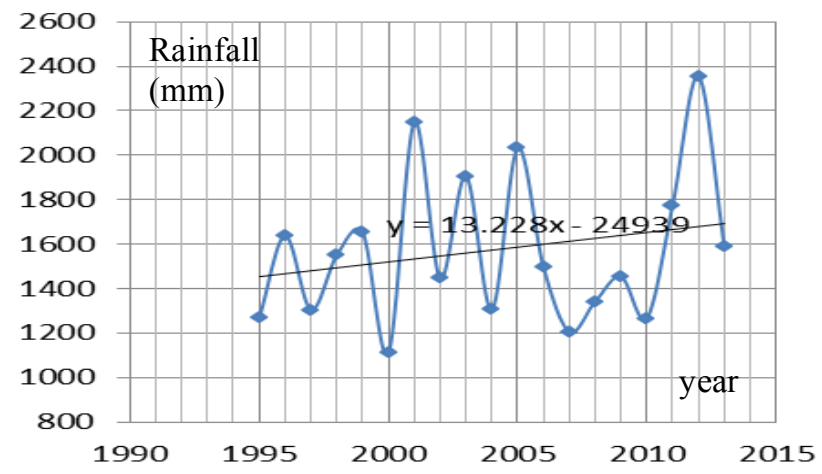

Figure 4. Rainfall in Thai Binh, 1995 - 2013

The main causes of these changes were that the Holocence aquifer was not the main aquifer used to extract groundwater for domestic purpose. This aquifer had directly hydraulic relationship with surface water resources. And the rainfall have been increasing during past years (Figure 4). That means there were recharged water resources and the factors of saline cleaning process for this aquifer.

\subsection{Pleistocene aquifer (qp)}

The distribution of saline and freshwater zones in Pleistocen aquifer was not changed so much. There was only a small change in some places of Dong Hung and Thai Thuy districts (Figure 5).

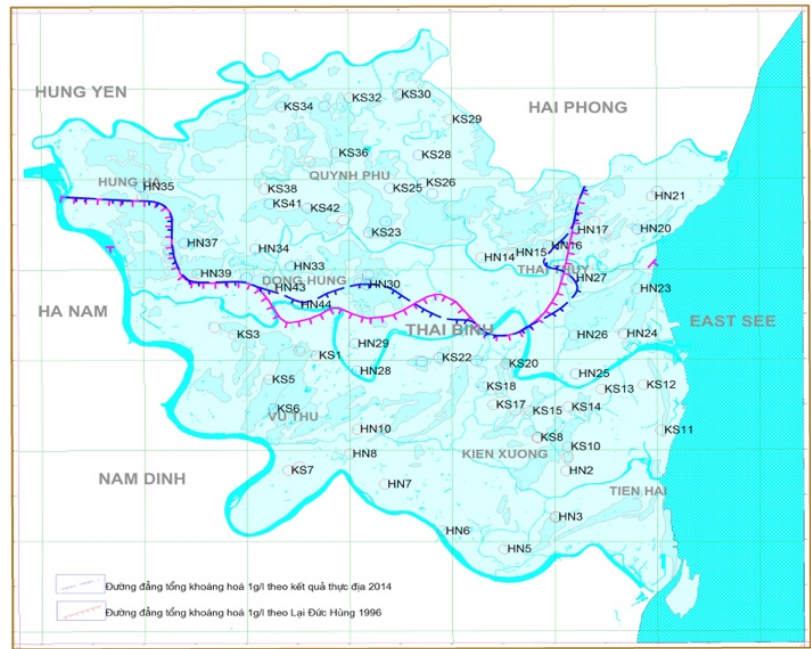

Figure 5. Distribution map of saline and fresh water areas in Pleistocen aquifer

According to observation and previous data, the flow direction of groundwater in this aquifer was from the North, West North to the South. Groundwater table in this aquifer was drawn down during the past years. Figure 6 shows the level of groundwater table at one of the National observation wells. 


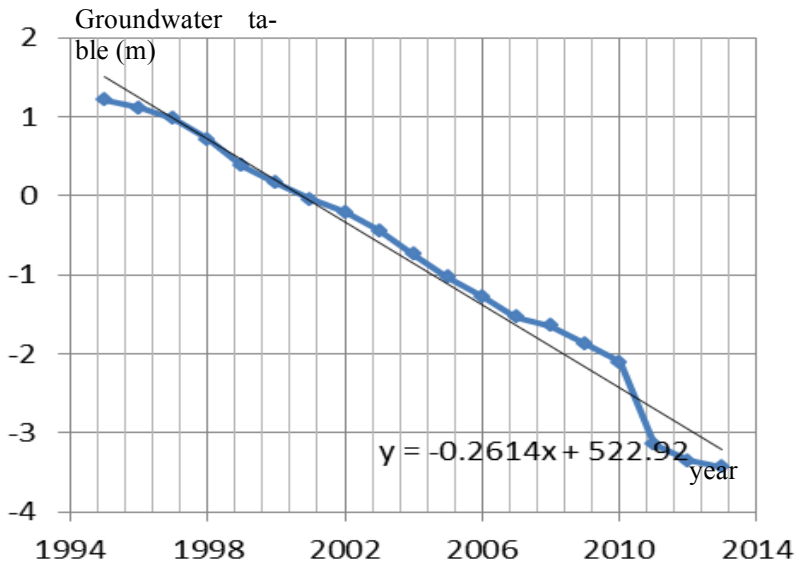

Figure 6. Level of groundwater in Pleistocene aquifer at National observation well $165 \mathrm{a}$
The cause making the changes in this aquifers was exploitation process which has been making groundwater level of this aquifer go down. However, the exploitation yield of groundwater in this area was not so high, nearly 300,000 $\mathrm{m}^{3} /$ day. According to statistic data of Thai Binh Department of natural resources and environment, the whole province had 216,926 wells funded by UNICEF with capacity about $200,000 \mathrm{~m}^{3} /$ day, 100 industrial exploitation wells with exploitation capacity about $20,852 \mathrm{~m}^{3} /$ day, and 6 groundwater treatment plants (Table 2).

The new distribution map of saline and feshwater zones in Holocen and Pleistocen aquifer will help managers give out reasonable exploiting and sustainable using methods for these natural resources.

Table 2. The percentage of the population using clean groundwater

\begin{tabular}{|c|c|c|c|c|c|c|c|}
\hline \multirow[b]{2}{*}{ No } & \multirow[b]{2}{*}{ District } & \multirow[b]{2}{*}{ Population } & \multicolumn{4}{|c|}{ Number people use clean water groundwater } & \multirow[b]{2}{*}{$\%$} \\
\hline & & & Private well & Dug well & $\begin{array}{c}\text { Water supply } \\
\text { system }\end{array}$ & Total & \\
\hline 1 & Thai Binh & 66.937 & 13.250 & 10.145 & 30.000 & 53.395 & 80 \\
\hline 2 & Kien Xuong & 237.410 & 38.460 & 37.895 & 8.001 & 84.356 & 35 \\
\hline 3 & Thai Thuy & 259.629 & 53.975 & 47.675 & 9.996 & 111.646 & 43 \\
\hline 4 & Dong Hung & 252.220 & 76.000 & 34.015 & 6.003 & 116.018 & 46 \\
\hline 5 & Hung $\mathrm{Ha}$ & 247.349 & 72.150 & 40.315 & 4.007 & 116.472 & 47 \\
\hline 6 & Quynh Phu & 240.013 & 74.200 & 48.655 & 6.240 & 129.095 & 54 \\
\hline 7 & Tien Hai & 206.874 & 27.040 & 34.930 & 5.172 & 67.142 & 32 \\
\hline 8 & Vu Thu & 228.726 & 36.850 & 43.960 & 4.003 & 84.813 & 35 \\
\hline
\end{tabular}

To manage and exploit groundwater sustainably, some proposals and solutions were given as follows: at some areas that the Pleistocene aquifer has TDS value higher than $1 \mathrm{~g} / 1$ such as in Tien Hai, Kien Xuong, Vu Thu districts and a part of Thai Thuy district, we can extract groundwater in the Holocene aquifer. Reducing the number of private wells and replacing them by water plants to protect the aquifer from pollution sources and to control exploitation activities. We can build exploitation well systems using Bank infiltration technology developed by Nagaoka - Japan to exploit groundwater in shallow aquifers with medium thickness in Holocene sediment.

In some areas as in Dong Hung, Quynh Phu, and Hung Ha districts where groundwater was exploited in the Pleistocene aquifer, we need to relocate reasonably the exploiting wells far away from the saline boundary to limit the movement of this boundary by exploitation process and reduce the number of individual wells to protect aquifer.

\section{Conclusion}

The new distribution of saline and fresh groundwater zones in Pleistocene and Holocene aquifers was found. In Holocene aquifer, the freshwater areas have been expanding through the saline cleaning process. Groundwater has close relationship with surface water sources and rainy water. We can exploit groundwater at the depth from 20 to $30 \mathrm{~m}$ by Bank infiltration technology at coastal districts such as Tien Hai and Thai Thuy.
In Pleistocene aquifer, the new distribution of saline and freshwater zones did not change so much in comparison with research result of previous scientists in the year 1996. We can exploit groundwater at the depth from 60 to $150 \mathrm{~m}$ in Hung Ha, Dong Hung, Quynh Phu districts and a part of Thai Thuy district but well fields need to be built far from the saline boundaries.

Finally, to manage and exploit groundwater safely and stably have to reduce the number of private boreholes and replace by water plants.

\section{References}

[1] Lai, D.H. (1996). Report of HydroGeology Mapping scale 1:50000 Thai Binh province. Northern division for water resources planning and investigation, $\mathrm{Ha}$ Noi.

[2] Le, T.T.Tam (2011). Research and assessment pollution of groundwater in Thai Binh province. Proposed solutions exploit, rational use of groundwater resources in a sustainable development. Institute of Geography - Viet Nam Academy of science and Technology.

[3] Pham, K.H. (2014) Bank infiltration well technology and potential applications in Vietnam to exploit water, Hanoi University of Mining and Geology.

[4] National Center for Water Resources Planning and Investigation (2012). Investigation and assessment 
the status exploitation and using groundwater of Thai Binh province.

[5] Sahli H., Tagorti M.A., Tlig, S. (2013). Groundwater hydrochmistry and mass transfer in stratified aquifer system (Jeffara - Gabes basin, Tunisia). Larhyss Journal, ISSN 1112 - 3680, no 12, Janvier 2013, pp
$95-108$.

[6] Yechieli, Y. (2000). Fresh - Saline Groundwater interface in Western Dead Sea Area. Ground water 38.no.4: $615-623$. 